\title{
Mapping Pyroclastic Flow Inundation Using Radar and Optical Satellite Images and Lahar Modeling
}

\author{
Chang-Wook Lee $\mathbb{D}^{1},{ }^{1}$ Zhong Lu $\mathbb{D}^{2},{ }^{2}$ in-Woo Kim, ${ }^{2}$ and Sung-Jae Park ${ }^{1}{ }^{1}$ \\ ${ }^{1}$ Division of Science Education, Kangwon National University, 1 Kangwondaehak-gil, Chuncheon-si, \\ Gangwon-do 24341, Republic of Korea \\ ${ }^{2}$ Huffington Department of Earth Sciences, Southern Methodist University, 3225 Daniel Avenue, Dallas, TX 75205, USA \\ Correspondence should be addressed to Zhong Lu; zhonglu@smu.edu
}

Received 29 May 2017; Revised 29 August 2017; Accepted 6 December 2017; Published 19 March 2018

Academic Editor: Jesus Corres

Copyright (c) 2018 Chang-Wook Lee et al. This is an open access article distributed under the Creative Commons Attribution License, which permits unrestricted use, distribution, and reproduction in any medium, provided the original work is properly cited.

\begin{abstract}
Sinabung volcano, located above the Sumatra subduction of the Indo-Australian plate under the Eurasian plate, became active in 2010 after about 400 years of quiescence. We use ALOS/PALSAR interferometric synthetic aperture radar (InSAR) images to measure surface deformation from February 2007 to January 2011. We model the observed preeruption inflation and coeruption deflation using Mogi and prolate spheroid sources to infer volume changes of the magma chamber. We interpret that the inflation was due to magma accumulation in a shallow reservoir beneath Mount Sinabung and attribute the deflation due to magma withdrawal from the shallow reservoir during the eruption as well as thermoelastic compaction of erupted material. The pyroclastic flow extent during the eruption is then derived from the LAHARZ model based on the coeruption volume from InSAR modeling and compared to that derived from the Landsat 7 Enhanced Thematic Mapper Plus (ETM+) image. The pyroclastic flow inundation extents between the two different methods agree at about $86 \%$, suggesting the capability of mapping pyroclastic flow inundation by combing radar and optical imagery as well as flow modeling.
\end{abstract}

\section{Introduction}

Volcanic pyroclastic flows consist of a large amount of destructive mass of very hot ash, lava fragments, and gases ejected explosively from a volcano and typically flow downslope at great speed. Volcanic pyroclastic flows pose great threats to people and property downstream from volcanoes. In order to accurately estimate the extents that are likely to be impacted by pyroclastic flows, computer models, such as LAHARZ [1], have been developed on the basis of statistical analyses of flow-path geometries and mathematical analyses of flow physics. LAHARZ [1] has been applied at many volcanoes worldwide.

Mount Sinabung is a stratovolcano in the northwestern part of the Sumatra Island, Indonesia (Figure 1). Formed during the Pleistocene to Holocene, the volcano consists of andesitic and dacitic lavas. The Sumatra Island, located on the boundary between the Australian Plate to the south and the Eurasian Plate to the north, was formed by the melting of subducted rocks under enormous pressure and its subsequent eruptions in volcanoes. Sumatra and Java, Indonesia, include a long line of volcanoes along the boundary between the two plates and have produced a large number of earthquakes and volcanic eruptions. Located within $50 \mathrm{~km}$ southeast of Sinabung, Sumatra Island's Toba volcano had the largest eruption with a volcanic explosivity index (VEI) of 8 in the geological record during last 25 million years [2].

Mount Sinabung has a $2460 \mathrm{~m}$ high conical structure with four overlapping craters about 60 to $300 \mathrm{~m}$ in diameter from north to south, respectively, and is mostly covered with dense vegetation exclusively at the top of the volcano (Figure 2). Sinabung volcano had its last historical activity about 400 years ago, and the 2010 eruption started on August 29 and lasted to the middle of September 2010. After the first reawakened volcanic eruption in 2010, Mount Sinabung erupted again in 2013, 2014, and 2016. 


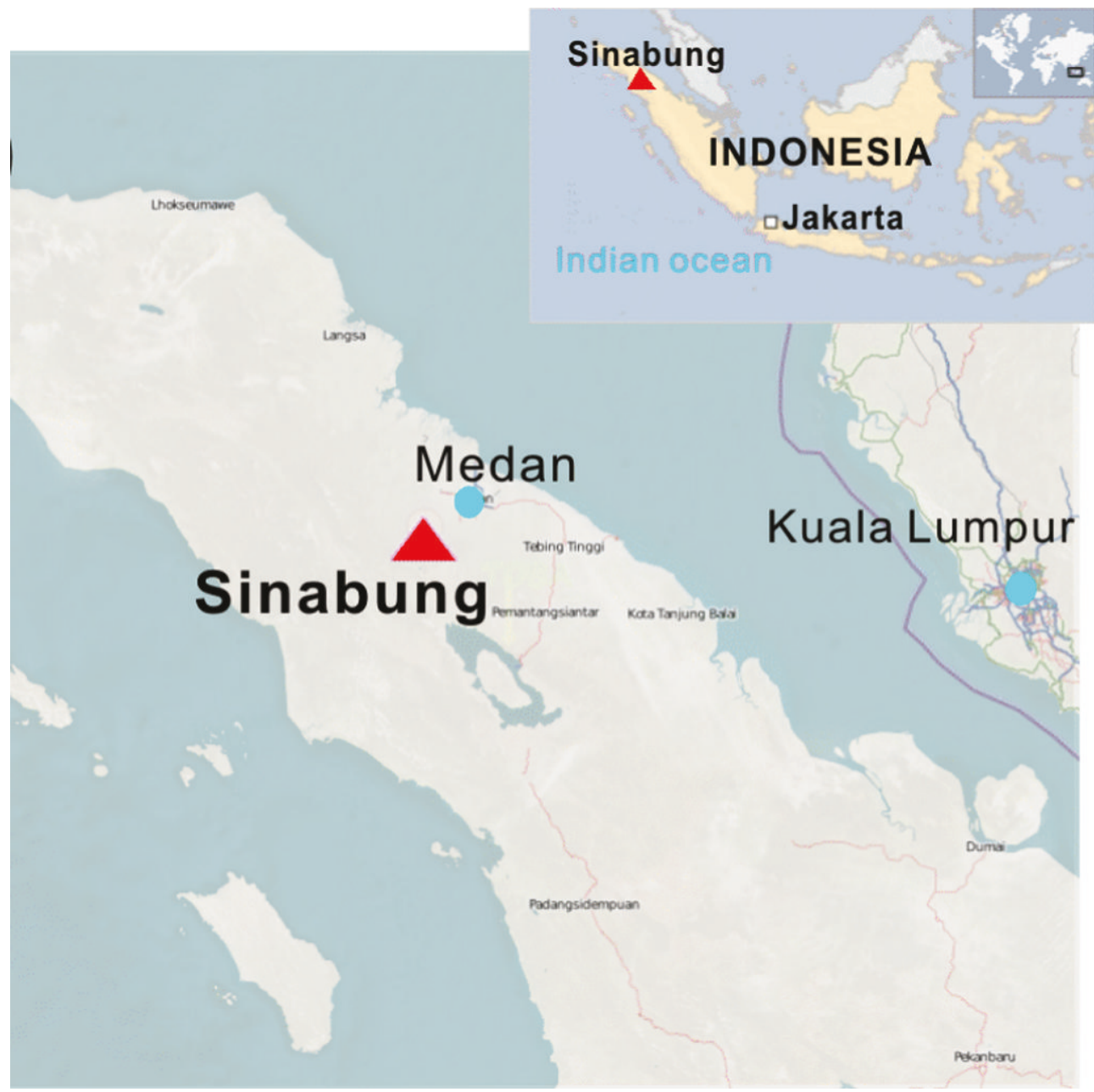

Figure 1: Location of Mount Sinabung in Indonesia above the Sumatra subduction zone.

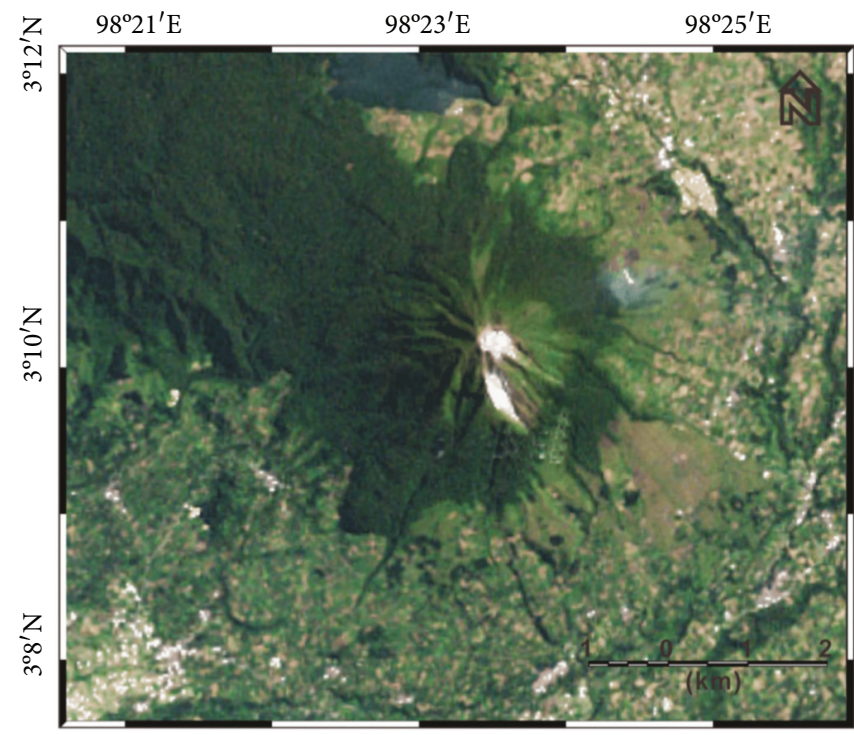

FIGURE 2: Landsat 7 ETM+ imagery at Mount Sinabung on 19 May 2003.

SAR interferometry (InSAR) is an efficient method for measuring surface deformation over large areas [3-7], and it has been applied worldwide to study volcanoes [8-13].
Chaussard and Amelung [10] processed 13 L-band ALOS/ PALSAR images acquired before 2010 and showed progressive inflation at a rate of $2.2 \mathrm{~cm} / \mathrm{yr}$ using small-baseline subset 


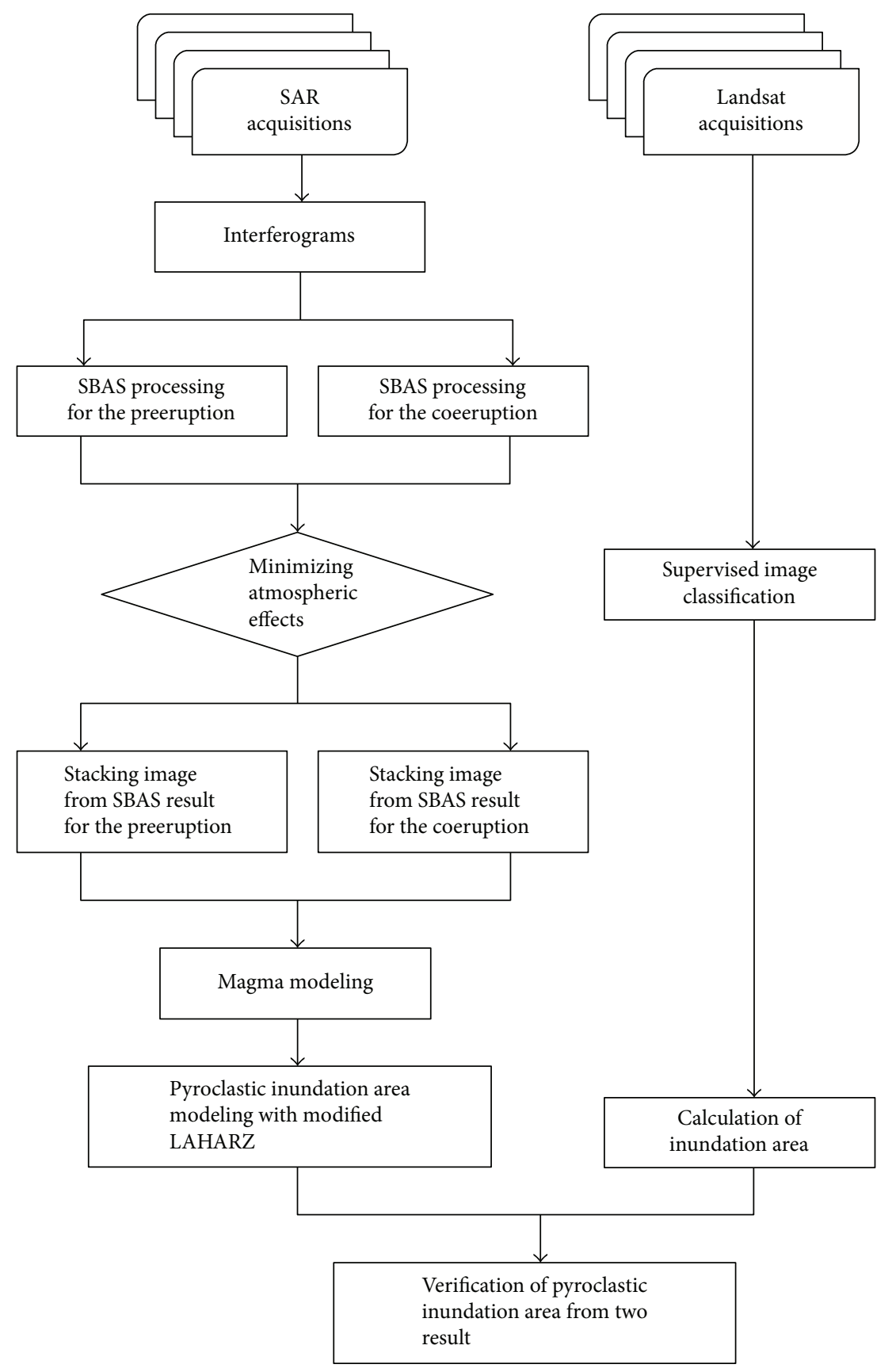

FIGURE 3: Flowchart of the radar and optical data processing.

(SBAS) InSAR technique [14-16]. They also measured the surface displacement before the eruption and during the eruption and estimated the depth of magma storage $(0.9 \mathrm{~km})$ using volcanic source modeling (i.e., Mogi and Yang) [17-21]. However, these previous InSAR studies did not calculate the substantive damages of the volcanic activities but merely observed the volume change of the magma chamber according to the arithmetical deformation of the surface.

In this study, we have carried out a study of pyroclastic flow mapping using satellite imagery from both radar and optical sensors as well as the LAHARZ program
(Figure 3). We improve the preliminary results [22-24] by laying out details on how to derive the pyroclastic flow extent using maximum likelihood classification method based on Landsat 7 images where artifacts due to scanline corrector have been rectified. We generate the coeruption InSAR image by stacking several interferograms in order to improve the signal-to-noise ratio (SNR) of the coeruption deformation map, based on which we derive the extrusion volume associated with the 2010 eruption at Sinabung from geophysical models. The goal is to generate a high-SNR deformation map for an accurate estimate of the eruption volume and improve the earlier 
TABLE 1: Characteristics of ALOS/PALSAR and Landsat data used in this study.

(a)

\begin{tabular}{|c|c|c|c|c|}
\hline Number & Mission & Orbit number & Date (YYYYMMDD) & Perpendicular baseline $(\mathrm{m})$ \\
\hline 1 & ALOS/PALSAR & 00702 & 20070220 & 0 \\
\hline 2 & ALOS/PALSAR & 00707 & 20070708 & 181 \\
\hline 3 & ALOS/PALSAR & 00708 & 20070823 & 205 \\
\hline 4 & ALOS/PALSAR & 00801 & 20080108 & 15 \\
\hline 5 & ALOS/PALSAR & 00802 & 20080223 & 194 \\
\hline 6 & ALOS/PALSAR & 00804 & 20080409 & 305 \\
\hline 7 & ALOS/PALSAR & 00805 & 20080525 & -45 \\
\hline 8 & ALOS/PALSAR & 00810 & 20081010 & -124 \\
\hline 9 & ALOS/PALSAR & 00901 & 20090110 & 101 \\
\hline 10 & ALOS/PALSAR & 00902 & 20090225 & -227 \\
\hline 11 & ALOS/PALSAR & 00907 & 20090713 & 449 \\
\hline 12 & ALOS/PALSAR & 00908 & 20090828 & 546 \\
\hline 13 & ALOS/PALSAR & 00911 & 20091128 & 147 \\
\hline 14 & ALOS/PALSAR & 01001 & 20100113 & -3 \\
\hline 15 & ALOS/PALSAR & 01002 & 20100228 & 189 \\
\hline 16 & ALOS/PALSAR & 01007 & 20100716 & 46 \\
\hline 17 & ALOS/PALSAR & 01008 & 20100831 & 202 \\
\hline 18 & ALOS/PALSAR & 01010 & 20101016 & 154 \\
\hline 19 & ALOS/PALSAR & 01012 & 20101201 & -165 \\
\hline 20 & ALOS/PALSAR & 01101 & 20110116 & 31 \\
\hline
\end{tabular}

(b)

\begin{tabular}{lcccc}
\hline Number & Mission & Path/Track & Date & Time (UTC) \\
\hline 1 & Landsat/ETM+ & $129 / 058$ & 20120730 & $03: 35: 52.8$ \\
\hline
\end{tabular}

results of time-series deformation measurements where noise was apparent in some individual InSAR images [22-24]. We derive the volume change associated with Sinabung's volcanic eruption in 2010 using mechanical modeling, and the calculated volume change of the magma chamber is then applied to a pyroclastic flow modeling algorithm based on LAHARZ [1, 25-27] to obtain the hazard zone of pyroclastic flow deposit. We describe in detail how we model the pyroclastic inundation map using the LAHARZ model and discuss quantitatively the comparison of pyroclastic flow simulation maps and pyroclastic flow map derived from the Landsat 7 ETM+ image of Sinabung volcano (Table 1). Finally, we highlight that the integration of satellite image analysis and pyroclastic flow simulation using the LAHARZ program can accomplish volcano monitoring and pyroclastic flow inundation hazard mapping of active volcanoes and discuss the limitation of the proposed method.

\section{Processing of Optical Image}

A pyroclastic flow inundation map can be generated by field surveys from the crater rim to the furthest extent of the pyroclastic flow after a volcanic eruption. However, a field survey in an active volcano can be dangerous due to the exposure to hazardous gases and abrupt activities. In contrast, remote sensing techniques are a useful tool for generating pyroclastic flow deposit maps, providing a safe, cost effective alternative to field mapping.

In this study, we aim to generate a pyroclastic flow deposit map using a Landsat 7 ETM+ image acquired on 30 Jul. 2012 after the 2010 Sinabung eruption (Table 1). This image represents the land cover after the 2010 eruptions with an absence of atmospheric effects (Figure 4(a)). However, the Landsat $7 \mathrm{ETM}+$ data suffer from an artifact due to the failure of the scan-line corrector (SLC) in the ETM+ instrument. The Landsat 7 data can be restored by a gap-filling and filtering technique described by Lee et al. [28, 29] (Figure 4(b)). Finally, we use the gap-filled Landsat 7 ETM+ data (Figure 4(b)) to derive land-cover types through supervised maximum likelihood classification (Figure 4(c)). We establish six classes, including farm land (orange), forest (green), city (gray), shadow (dark gray), water (blue), and pyroclastic flow deposit area (red). Based on the classification maps, the pyroclastic flow deposits from the 2010 eruption were mainly contained over the southern and eastern upper flanks of the volcano (red in Figure 4(c)). The pyroclastic flow inundation 


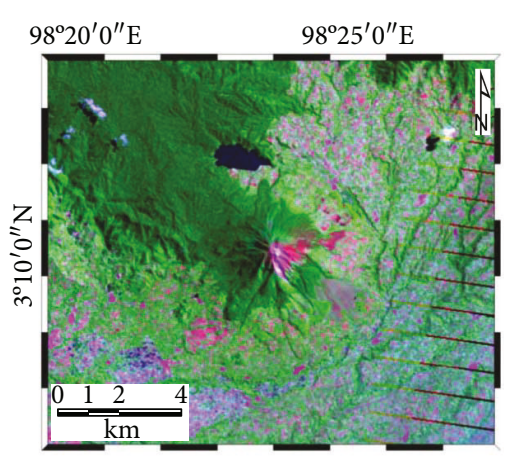

(a)
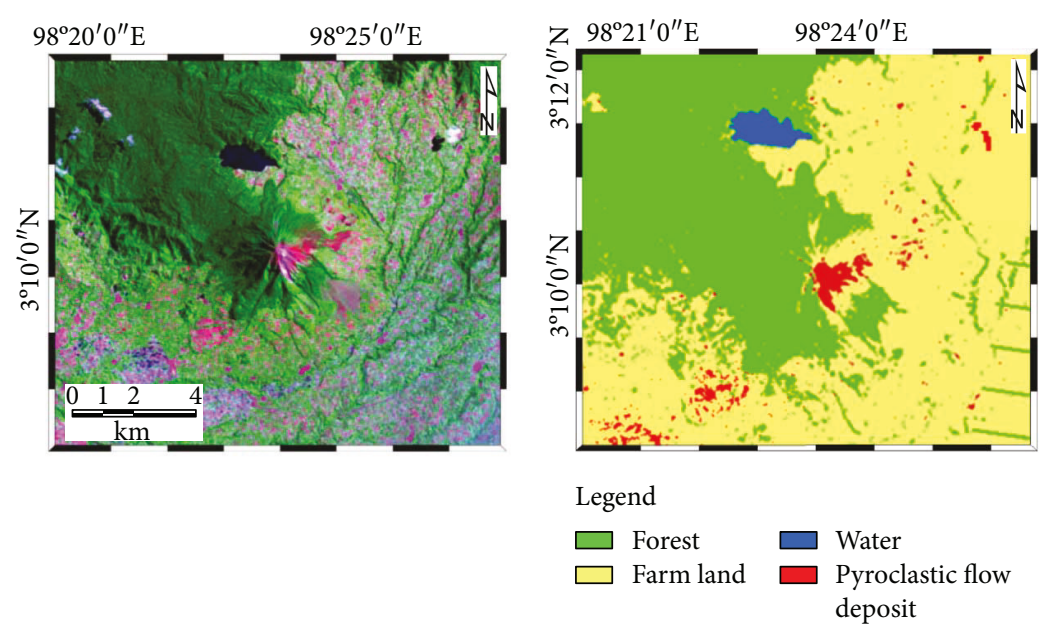

(c)

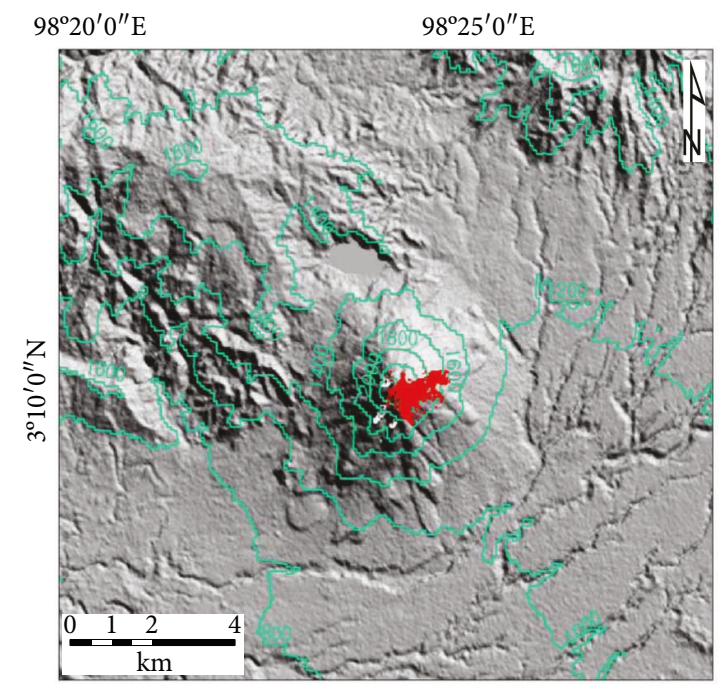

(d)

Figure 4: (a) False color composite $(\mathrm{RGB}=742)$ image of Landsat 7 ETM+ acquired on 30 Jul. 2012. (b) The gap-filled Landsat 7 ETM+ image. (c) Supervised classification map derived from (b). (d) Pyroclastic flow inundation after the 2010 eruption at Sinabung volcano.

area after the 2010 eruption of Sinabung volcano is estimated as $0.872 \mathrm{~km}^{2}$ (red in Figure $4(\mathrm{~d})$ ).

\section{Processing of Radar Images}

InSAR processing is carried out to characterize the surface deformation of the Sinabung volcano. Using 20 ALOS/PALSAR images from 20 Feb. 2007 to 16 Jan. 2011 (Table 1), 40 interferograms are generated. The best coherence was constrained on the volcano summit. Outside the summit, coherence was maintained only at many scattered patches of rocky and less-vegetated areas.

The trend of surface deformation shows an uplift pattern until the end of August 2010 but a deflation pattern from the eruption event to the end of the dataset, corresponding to the changes in magma volume inside the reservoir. Therefore, we divide our results into two different periods of inflation and deflation separated by the onset of the 2010 eruption. The time-series SBAS technique is applied to measure the surface deformation of the Sinabung volcano at each period [16]. Using this method, we can minimize artificial atmospheric effects $[30,31]$ and accurately measure surface deformation over a specific time period. Figure 5(a) displays the stacked image showing inflation of magma volume change until the 2010 eruption, and Figure 5(b) represents the stacked image that shows the deflation pattern of surface deformation during the 2010 eruption.

The two stacked images of surface deformation (Figures 6(a) and 6(b)) have opposite fringe tendency, with a maximum $1.2 \mathrm{~cm} / \mathrm{yr}$ of preeruption inflation (Figure 6(c)) and $7 \mathrm{~cm} / \mathrm{yr}$ of coeruption deflation (Figure $6(\mathrm{~d})$ ).

\section{Volume Change Model of Magma Chamber}

The Mogi model, based on a point source embedded in an elastic homogeneous half-space [32], is applied to estimate the location and volume change of the mean surface deformation rate maps (Figures 6(a) and 6(b)) before and during 


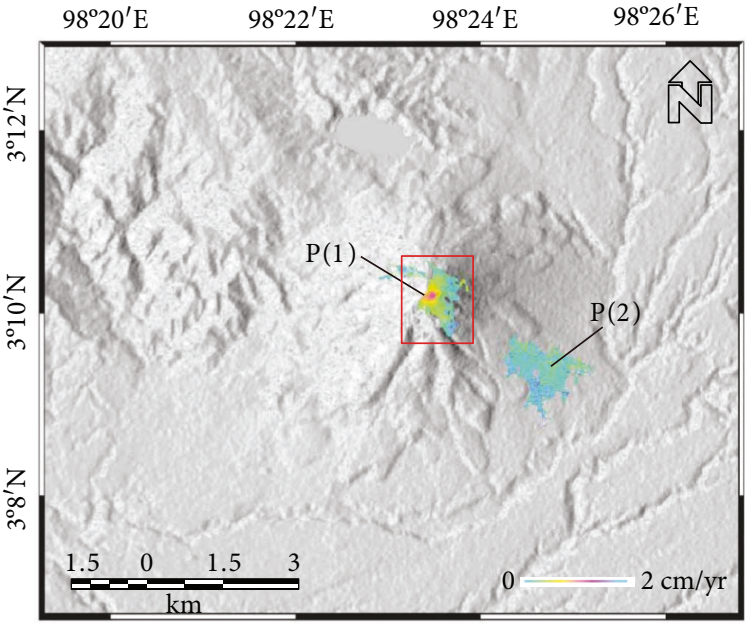

(a)

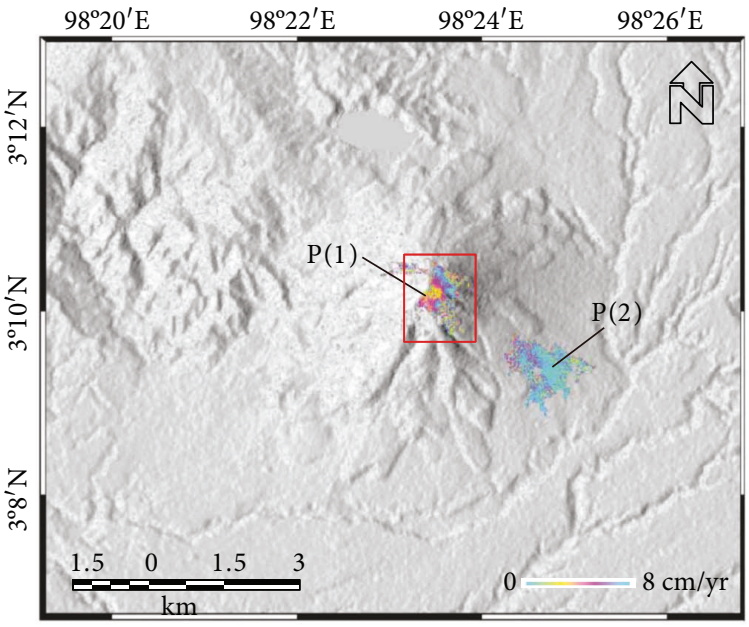

(b)

FIGURE 5: Stacked unwrapped interferograms for preeruption (a) and coeruption (b) of Sinabung volcano (modified from [16]).

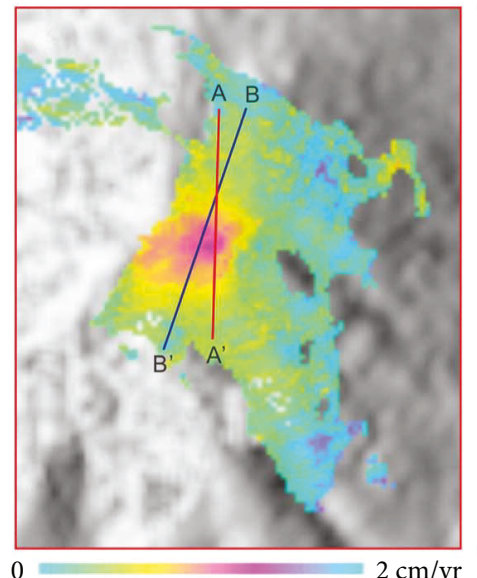

(a)

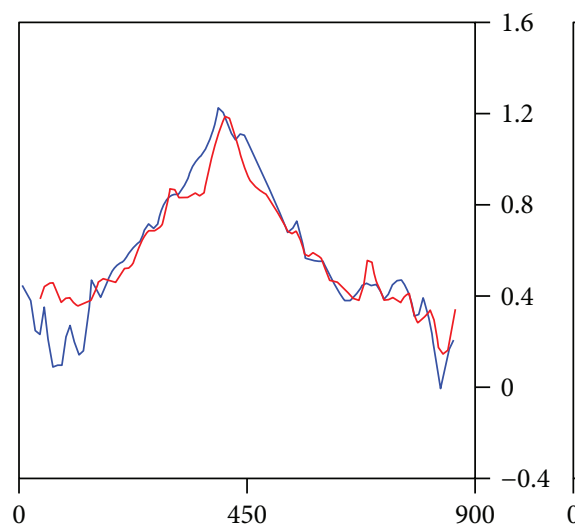

Distance $(\mathrm{m})$

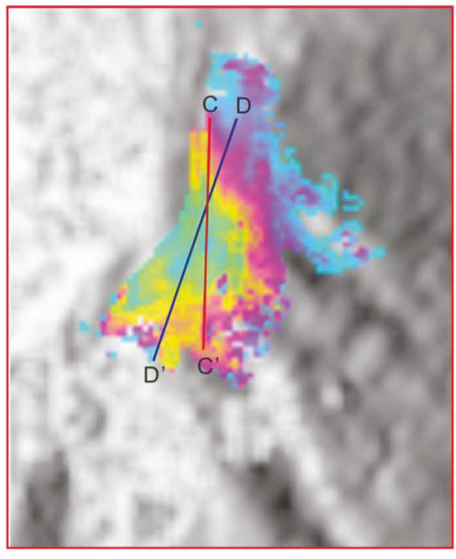

(b)

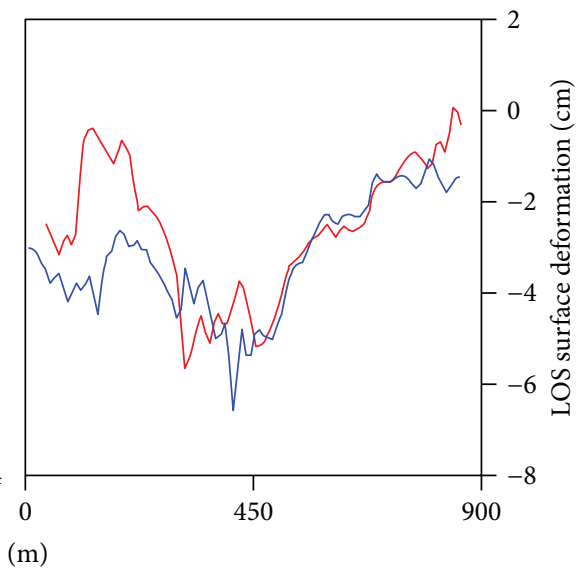

$\mathrm{A}-\mathrm{A}^{\prime}$
$\mathrm{B}-\mathrm{B}^{\prime}$

$-\mathrm{C}-\mathrm{C}^{\prime}$

D-D'

(c)

(d)

Figure 6: (a) and (b) are magnified images in Figures 4(a) and 4(b) with the cross lines of A, B, C, and D. (c) and (d) represent the profile of averaged surface deformation along each cross line (modified from [16]). 
the eruption. The best-fit Mogi source models of the observed interferograms (Figures $7(\mathrm{a})$ and $7(\mathrm{~b})$ ) are represented by synthetic interferograms in Figures 6(c) and 6(d). Residual interferograms (Figures $7(\mathrm{~g})$ and $7(\mathrm{~h})$ ) can be calculated from the difference between the observed and synthetic interferograms. The depth of source is estimated to be $\sim 0.3 \mathrm{~km}$ below sea level (BSL) before eruption and $\sim 0.6 \mathrm{~km}$ BSL during the eruption (Table 2). This Mogi model estimates an increase in volume before the eruption as $1.9 \times 10^{-6} \mathrm{~km}^{3} / \mathrm{yr}$ (Figure 7). During the deflation of the coeruption period, the volume decrease is estimated to be $-2.7 \times 10^{-5} \mathrm{~km}^{3} / \mathrm{yr}$ (Figure 7). As the Mogi model is essentially a point source, we further generate a best-fit model for using a prolate spheroid [8] for the preeruption and coeruption periods. The prolate spheroid source model (Figure 7(e)) is calculated to be at a depth of $1.3 \mathrm{~km}$ BSL beneath the center of the caldera before the eruption and $\sim 1.1 \mathrm{~km}$ BSL during the eruption. The RMSE between the observations and model predictions from the prolate spheroid model is less than the corresponding one from the Mogi source (Table 2). Results from the prolate spheroid model suggest that the source of coeruption deflation is a steeply dipping elongate spheroid with major and minor axes of $2.7 \mathrm{~km}$ and $1.2 \mathrm{~km}$, respectively, and a loss in pressure of $-62.2 \mathrm{MPa} / \mathrm{yr}$ (Table 3 ). The preeruption source axes are estimated to be $3.0 \mathrm{~km}$ and $2.4 \mathrm{~km}$ with an increased pressure of $4.3 \mathrm{MPa} / \mathrm{yr}$ (Table 3 ).

\section{LAHARZ Processing}

The rationale for the delineation of lahar-inundation hazard zones $[33,34]$ is derived from the scaling analysis of lahar paths and statistical analysis using the LAHARZ program [35-37]. These analyses generate semiempirical equations that predict the inundated valley cross-sectional area (1) and the planimetric area (2) as a function of lahar volume with proportionality coefficients $c$ and $C$ using volcanic event data of 27 paths of lahars at nine volcanoes.

$$
\begin{aligned}
& \log A=\log C+\frac{2}{3} \log V, \\
& \log B=\log c+\frac{2}{3} \log V,
\end{aligned}
$$

where $A$ is the cross-sectional area, $B$ is the planimetric area, $c$ and $C$ are proportionality coefficients, and $V$ is the volume of the lahar. These calibrated predictive equations involve all the information needed to calculate and plot inundation on topographic maps through an empirical formula. Statistical methods from the LAHARZ program result in experience coefficients, $C$ and $c, C=0.05$ and $c=200((3)$ and (4)).

$$
\begin{aligned}
& A=0.05 V^{2 / 3}, \\
& B=200 V^{2 / 3} .
\end{aligned}
$$

PF inundation maps are generated in this study using a statistically constrained simulation model to estimate potential hazard areas [25] by adapting methodology from the
LAHARZ program [35]. The prediction equations for cross-sectional (5) and planimetric (6) areas of PF hazards for Sinabung volcano are calibrated using data from dozens of events at several volcanoes. The equations are expressed with empirical proportionality coefficients $(C=0.05$ to 0.1 , $c=35$ to 40 ) resulting from the adaptation of LAHARZ program statistical analyses [35].

$$
\begin{aligned}
& A=(0.05 \text { to } 0.1) V^{2 / 3}, \\
& B=(35 \text { to } 40) V^{2 / 3} .
\end{aligned}
$$

The PF inundation map for the 2010 Sinabung eruption is created in this study using the PF modeling algorithm from the modified LAHARZ program with empirical coefficient values of 0.1 for $C$ and 40 for $c$. Several values for the volume of the pyroclastic flow in (5) and (6) are tested, including the volume change estimate calculated using the Mogi model with deformation observed in the coeruption interferogram (Table 2).

The inundation maps for the PF (Figure 8) estimated from the LAHARZ program can be compared to the results of the supervised classification created using the posteruptive Landsat 7 ETM+ image from 30 Jul. 2012. The modified LAHARZ program estimates are calculated using the four different values for the PF volume (red, brown, orange, and yellow colors).

Among the four different values for volume tested using the modified LAHARZ method, the volume of $-2.7 \times 10^{-5} \mathrm{~km}^{3}$ (red color) agrees relatively well with the result from the supervised classification delineation for the inundation limits of the PF deposits from the Landsat image. Region B (volume of PF simulation) in Table 4 is also included within approximately $84 \%$ of the PF inundation area delineated using the Landsat image. Region A represents a too small PF simulation area compared with the Landsat image result. Regions $\mathrm{C}$ and $\mathrm{D}$, however, have common areas of only $78 \%$ and $67 \%$, respectively, between the PF simulations and pyroclastic inundation extents based on the Landsat image (Figure 8).

\section{Discussion}

InSAR images over Sinabung indicate volcanic inflation before the 2010 eruption and deflation during the eruption. Modeling the observed deformation using Mogi and prolate spheroid sources has allowed us to estimate the magma source location, excessive pressure, the shape of the source, and volume changes during the preeruption and coeruption periods. The model results suggest there is a magma storage underneath Sinabung. The reservoir is located $\sim 1 \mathrm{~km}$ BSL ( $\sim 3 \mathrm{~km}$ beneath the peak of Sinabung). The magma reservoir is best characterized with a prolate spheroid with the vertical axis of $\sim 2.7 \mathrm{~km}$ and horizontal axis of $1.2 \mathrm{~km}$.

The location of the shallow magma reservoir matches the observations of seismicity recorded by the local seismic network. The Indonesia's Centre for Volcanology and Geological Hazard Mitigation (CVGHM) installed four seismic stations (KWR, SKN, SKM, and MRD; green stars in 


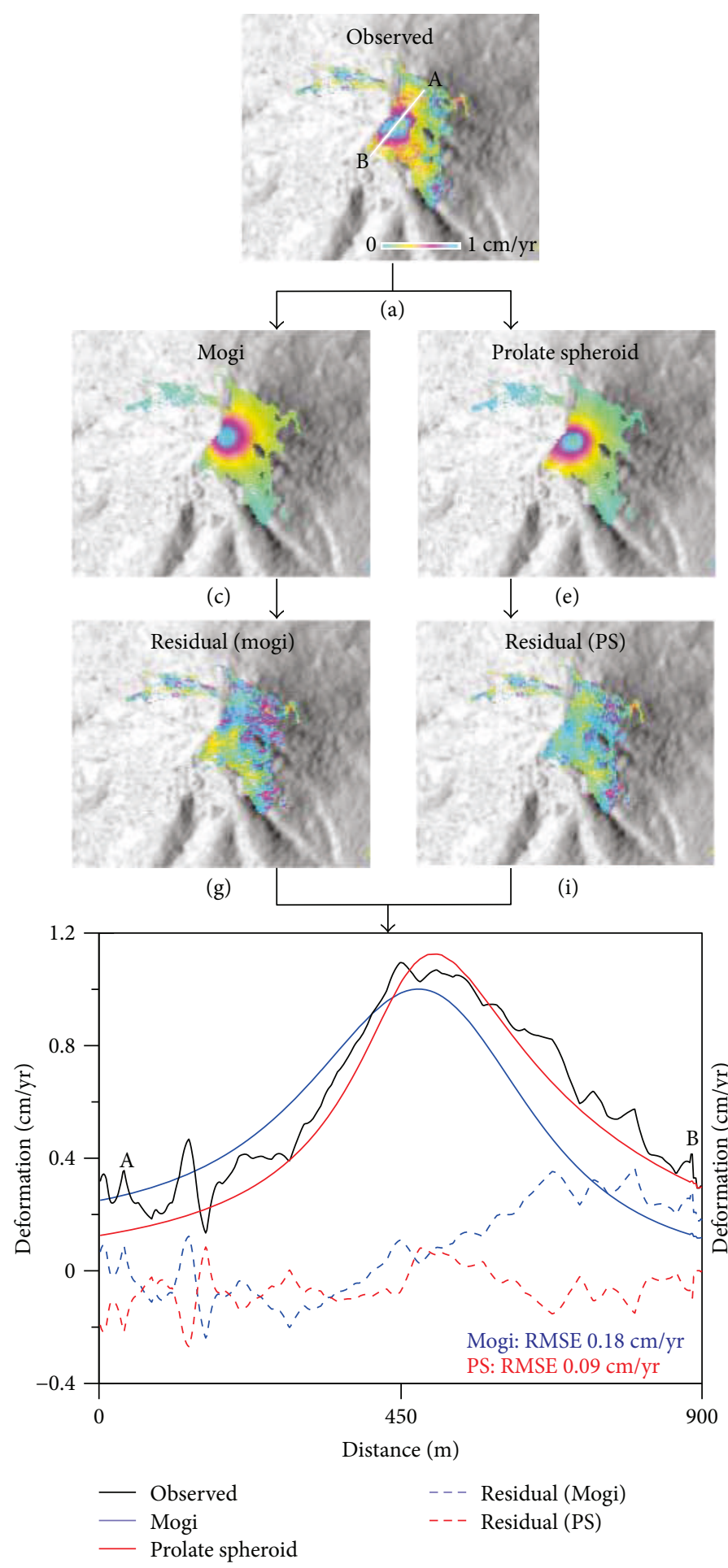

$(\mathrm{k})$
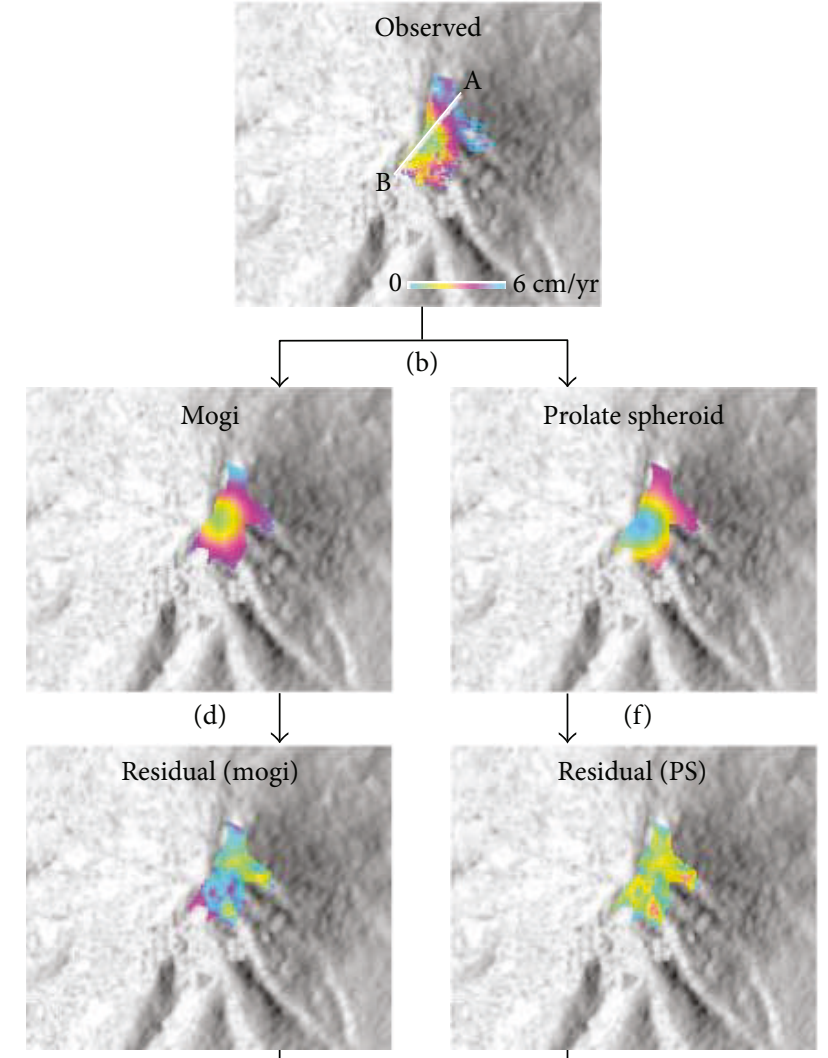

(h)

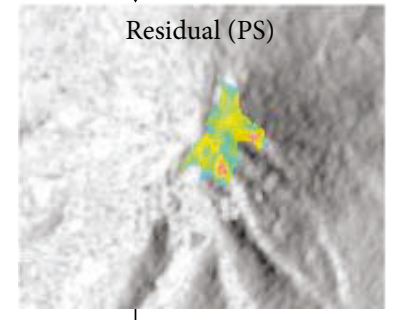

(j)

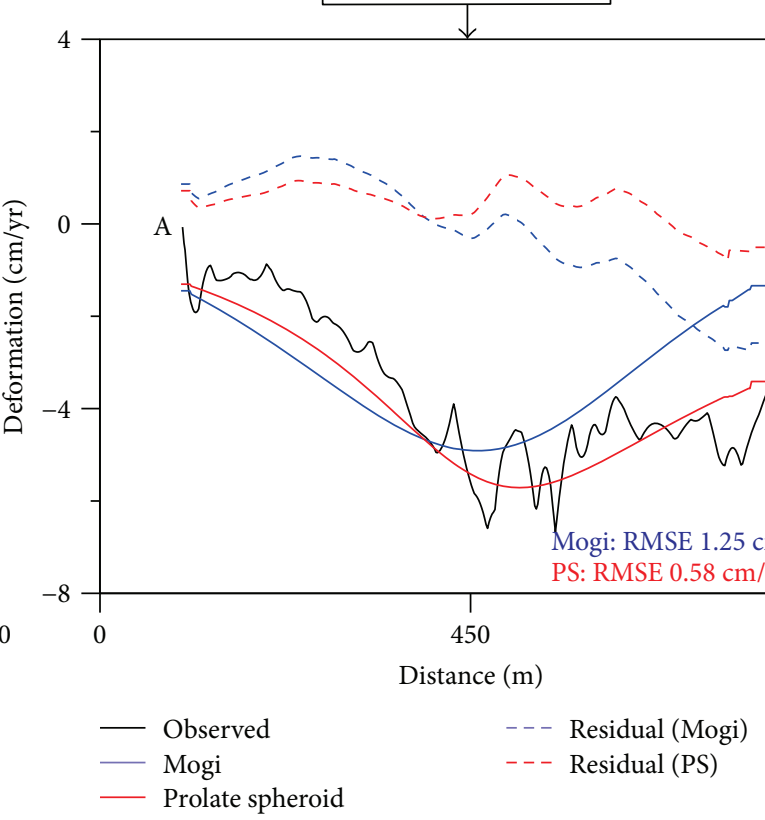

(1)

FIGURE 7: Application of Mogi and prolate spheroid models to the observed mean surface deformation maps during the preeruption and coeruption periods.

Figure 9(a)) around the crater area of Sinabung after the first eruption on 29 Aug. 2010. These stations recorded earthquakes that occurred on September 6 and 7 (red and blue circles in Figure 9(a)). Figure 9(b) displays hypocenters and the depths of earthquakes that occurred before and after another eruption on 7 Sept. 2010 [38]. A magma reservoir at $\sim 1 \mathrm{~km}$ BSL under the peak of Sinabung seems to be consistent with the fact that most earthquakes are located shallower than 
TABLE 2: Source parameters obtained from the Mogi model.

\begin{tabular}{lccc}
\hline & Depth $(\mathrm{km})$ & $\Delta V\left(\mathrm{~km}^{3} / \mathrm{yr}\right)$ & RMSE $(\mathrm{cm} / \mathrm{yr})$ between line A and B \\
\hline Preeruption (inflation pattern) & 0.3 & $1.9 \times 10^{-6}$ & 0.18 \\
Coeruption (deflation pattern) & 0.6 & $-2.7 \times 10^{-5}$ & 1.25 \\
\hline
\end{tabular}

TABLE 3: Source parameters obtained from the prolate spheroid model.

\begin{tabular}{lccccc}
\hline & Major axis $(\mathrm{km})$ & Minor axis $(\mathrm{km})$ & Depth $(\mathrm{km})$ & $\Delta P(\mathrm{MPa} / \mathrm{yr})$ & RMSE $(\mathrm{cm} / \mathrm{yr})$ between line A and B \\
\hline Preeruption (inflation pattern) & 3.0 & 2.4 & 1.3 & 4.3 & 0.09 \\
Coeruption (deflation pattern) & 2.7 & 1.2 & 1.1 & -62.2 & 0.58 \\
\hline
\end{tabular}

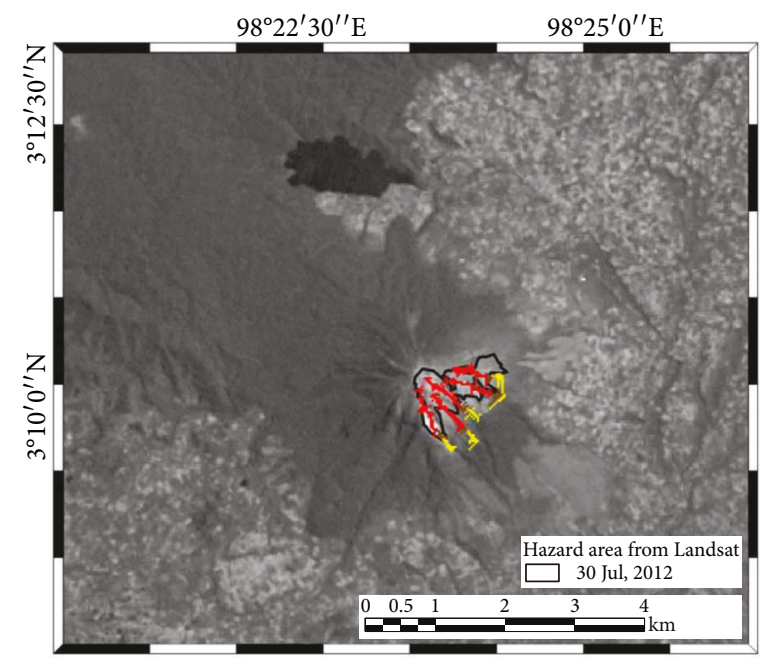

Pyroclastic flow volume $\left(\mathrm{m}^{3}\right)$

$\begin{array}{ll}\text { Region A } & \text { Region C } \\ \text { 20,000 (area: } 0.509 \mathrm{~km}^{3} \text { ) } & \square 30,000 \text { (area: } 0.646 \mathrm{~km}^{3} \text { ) } \\ \text { Region B } & \text { Region D } \\ 27,000 \text { (area: } 0.622 \mathrm{~km}^{3} \text { ) } & \square 40,000 \text { (area: } 0.792 \mathrm{~km}^{3} \text { ) }\end{array}$

(a)

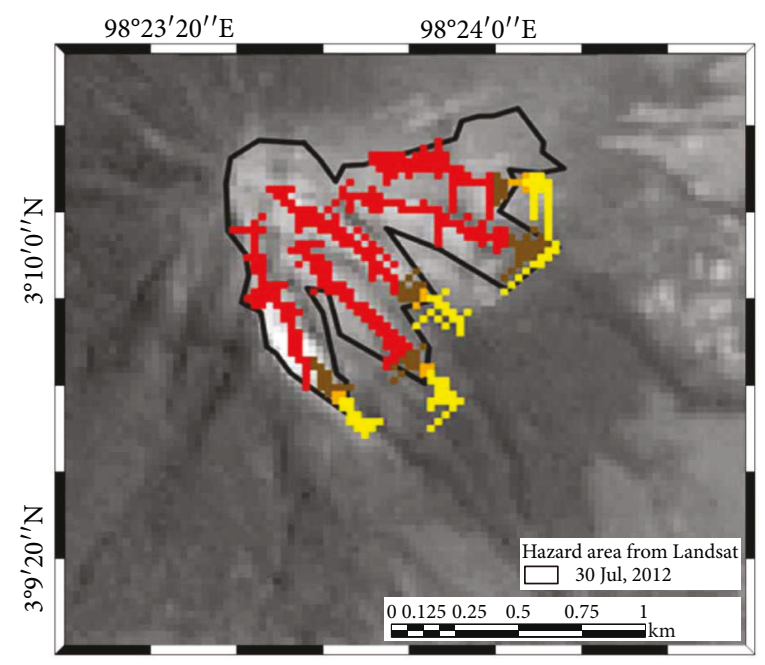

Pyroclastic flow volume $\left(\mathrm{m}^{3}\right)$

$\begin{array}{ll}\text { Region A } & \text { Region C } \\ 20,000 \text { (area: } 0.509 \mathrm{~km}^{3} \text { ) } & \square 30,000\left(\text { area: } 0.646 \mathrm{~km}^{3} \text { ) }\right. \\ \text { Region B } & \text { Region D } \\ 27,000 \text { (area: } 0.622 \mathrm{~km}^{3} \text { ) } & \square 40,000\left(\text { area: } 0.792 \mathrm{~km}^{3} \text { ) }\right.\end{array}$

(b)

FIgURE 8: The pyroclastic flow inundation area (a) estimated from the revised LAHARZ program (PF simulation) with various volumes $\left(20,000,27,000,30,000\right.$, and $\left.40,000 \mathrm{~m}^{3}\right)$. The black line $(\mathrm{b})$ is the pyroclastic flow inundation area from the supervised classification of the Landsat image acquired on 30 Jul. 2012 (after the 2010 eruption).

$1 \mathrm{~km}$ BSL (Figure 9). Such a magma reservoir is responsible for the observed inflation before the 2010 eruption and the deflation associated with the 2010 eruption.

Pyroclastic inundation hazard maps are generated in this study based on a modified LAHARZ program (PF simulation) using the volume change calculated by the Mogi model from the deformation results observed using stacked interferograms and then are compared with the inundation map from the supervised classification method with Landsat imagery. When we generate these pyroclastic inundation hazard maps, the volume change associated with the deflation of the magma chamber after the eruption was found to be the better-fit value (approximately $86 \%$ overlap) based on the comparison with the pyroclastic inundation maps from the Landsat images and the other PF simulations. This study has demonstrated that a volcano hazard inundation map can be generated using the PF model [25] by inputting parameters estimated from models of the magma chamber based on InSAR-derived surface deformation measurements. However, our method has some limitations. First, the eruption volume is calculated from the volume change by modeling the volcanic deflation from InSAR. Due to the vascularity, the eruption volume can be different from the deflation volume [8]. Hence, the volume used for LAHARZ modeling represents the lower bound of the volume of eruptive material. Second, we have ignored other eruptive products such as volcanic ash, which can lower our estimate for the volume used in LAHARZ modeling. Third, we have also neglected other thermodynamic effects on the magma chamber in 
TABLE 4: Comparison of the common region between the pyroclastic flow (PF) simulation and Landsat supervised classification hazard zone in Figure 7.

\begin{tabular}{|c|c|c|c|c|}
\hline Pyroclastic flow volume $\left(\mathrm{m}^{3}\right)$ & $\begin{array}{l}\text { Orientation } \\
\text { (direction) }\end{array}$ & $\begin{array}{l}\text { Common region between Landsat } \\
\text { and PF simulation (pixels) }\end{array}$ & $\begin{array}{l}\text { Pyroclastic flow inundation area } \\
\text { from PF simulation (pixels) }\end{array}$ & $\begin{array}{c}\text { Proportion of } \\
\text { common region (\%) }\end{array}$ \\
\hline \multirow{5}{*}{ Region A 20,000 } & $\mathrm{E}$ & \multirow{4}{*}{ Underestimated } & \multirow{4}{*}{ Underestimated } & \multirow{4}{*}{ Underestimated } \\
\hline & SE & & & \\
\hline & SSE & & & \\
\hline & S & & & \\
\hline & Total & - & - & - \\
\hline \multirow{5}{*}{ Region B 27,000 } & $\mathrm{E}$ & 252 & 284 & 88.73 \\
\hline & SE & 110 & 134 & 82.09 \\
\hline & SSE & 90 & 136 & 66.18 \\
\hline & S & 130 & 138 & 94.20 \\
\hline & Total & 582 & 692 & 84.10 \\
\hline \multirow{5}{*}{ Region C 30,000 } & $\mathrm{E}$ & 256 & 292 & 87.67 \\
\hline & SE & 110 & 140 & 78.57 \\
\hline & SSE & 60 & 142 & 42.25 \\
\hline & S & 136 & 144 & 94.44 \\
\hline & Total & 562 & 718 & 78.27 \\
\hline \multirow{5}{*}{ Region E 40,000 } & $\mathrm{E}$ & 272 & 356 & 76.40 \\
\hline & SE & 110 & 170 & 64.71 \\
\hline & SSE & 60 & 174 & 34.48 \\
\hline & S & 144 & 180 & 80.00 \\
\hline & Total & 586 & 880 & 66.59 \\
\hline \multirow{5}{*}{ Region F 50,000 } & $\mathrm{E}$ & 272 & 402 & 67.66 \\
\hline & SE & 110 & 204 & 53.92 \\
\hline & SSE & 60 & 198 & 30.30 \\
\hline & $S$ & 144 & 204 & 70.59 \\
\hline & Total & 586 & 1008 & 58.13 \\
\hline \multirow{5}{*}{ Region G 60,000 } & $\mathrm{E}$ & 272 & 474 & 57.38 \\
\hline & SE & 110 & 230 & 47.83 \\
\hline & SSE & 60 & 238 & 25.21 \\
\hline & $S$ & 144 & 226 & 63.72 \\
\hline & Total & 586 & 1168 & 50.17 \\
\hline \multirow{5}{*}{ Region $\mathrm{H}$ 70,000 } & $E$ & 272 & 500 & 54.40 \\
\hline & SE & 110 & 262 & 41.98 \\
\hline & SSE & 60 & 252 & 23.81 \\
\hline & S & 144 & 258 & 55.81 \\
\hline & Total & 586 & 1272 & 46.07 \\
\hline
\end{tabular}

the derivation of a deflation volcano from InSAR-derived deformation measurements [8].

\section{Conclusions}

In this study, we firstly measure the mean surface deformation using stacked interferograms by ALOS/PALSAR data before and after the 2010 eruption of Sinabung volcano on the Island of Sumatra, Indonesia. The mean surface deformation rate maps are used in the Mogi and spheroid models to estimate the depth, volume changes, and dimensions of the magma source before and during the 2010 eruption. The estimated depth of the magma source is around $1 \mathrm{~km} \mathrm{BSL}$; the volume change during the coeruption is calculated. The change in volume estimated from the Mogi model is used to generate a PF inundation hazard map using the modified LAHARZ program. We finally have verified the pyroclastic flow inundation area using the inundation map from the supervised classification method based on Landsat 7 ETM+ imagery. The best-fit result is when the volume for the PF simulation is based on the volume change from modeling the coeruption InSAR deformation map. We conclude that the combination of satellite image analysis and PF simulation using 


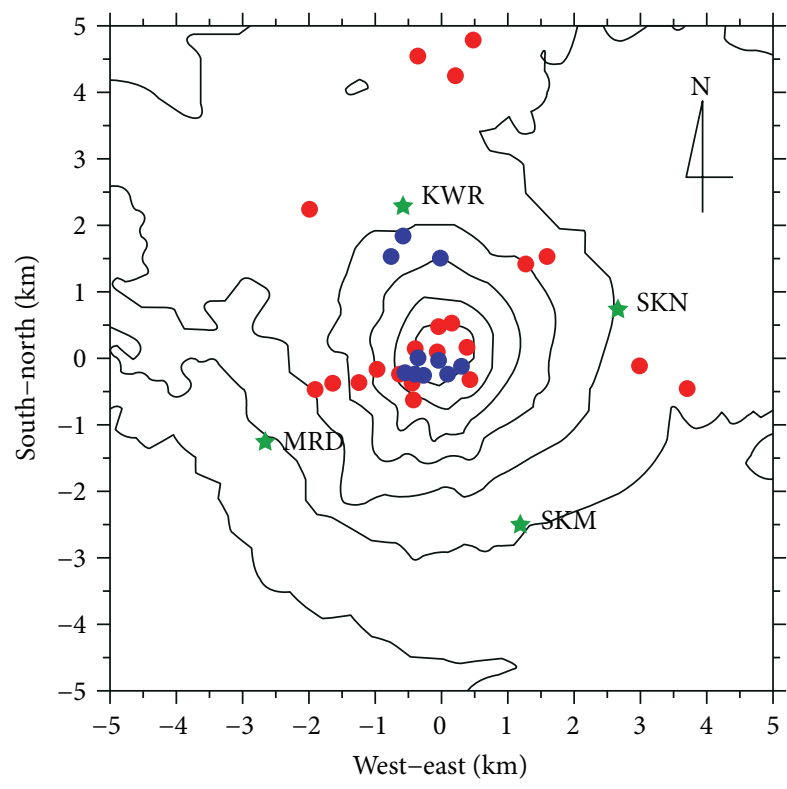

(a)

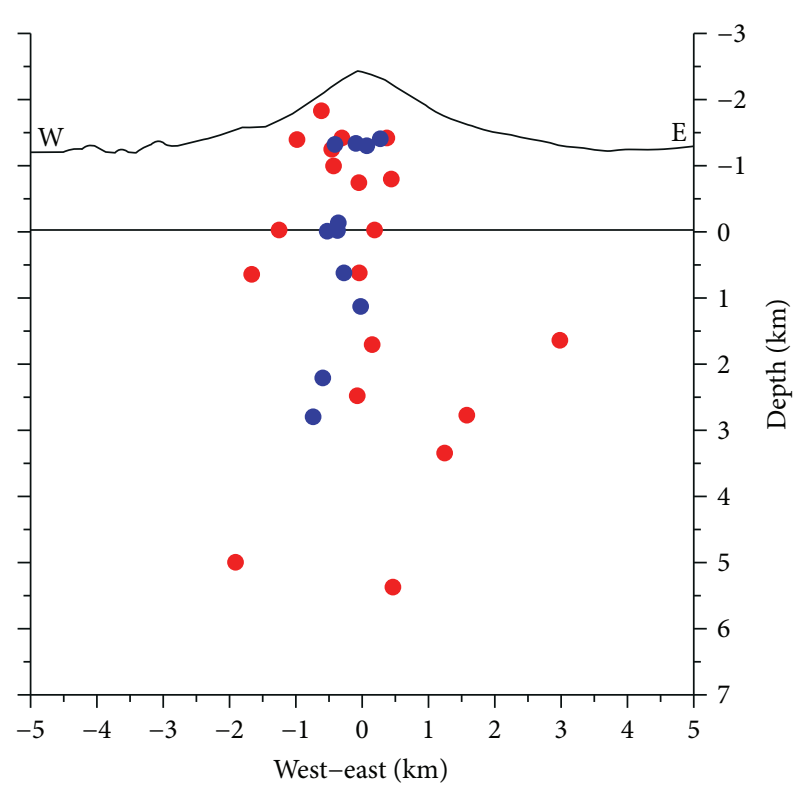

(b)

Figure 9: (a) Hypocentral distribution of volcanic earthquakes at Sinabung volcano from 6 to 7 Sept. 2010. Green stars indicate the locations of seismic survey stations. Red and blue dots indicate hypocenters before and after the eruption of 7 Sept. 2010 (from [38]).

the modified LAHARZ program can accomplish volcano monitoring and pyroclastic flow inundation hazard mapping of active volcanoes.

\section{Conflicts of Interest}

The authors declare that they have no conflicts of interest.

\section{Acknowledgments}

This research was supported by the National Research Foundation of Korea (NRF) grant funded by the Korea government (MSIP) (no. 2017R1A2B4003258); the Basic Science Research Program through the National Research Foundation of Korea (NRF) funded by the Ministry of Science, ICT \& Future Planning (2015M1A3A3A02013416); and the Korea Meteorological Administration Research and Development Program under Grant KMIPA (2015-3071). The SAR data used in this study are copyrighted @JAXA/METI and were provided by Alaska Satellite Facility.

\section{References}

[1] S.-P. Schilling, "LAHARZ: GIS programs for automated delineation of lahar hazard zones," U.S. Geological Survey Open-file Report 98-638, Reston, Virginia, 1998.

[2] Global Volcanism Program, Smithsonianhttp://volcano.si. edu/.

[3] D. Massonnet and K.-L. Feigl, "Radar interferometry and its application to changes in the Earth's surface," Reviews of Geophysics, vol. 36, no. 4, pp. 441-500, 1998.
[4] E. Rignot, "Changes in West Antarctic ice stream dynamics observed with ALOS PALSAR data," Geophysical Research Letters, vol. 35, no. 12, 2008.

[5] A.-H.-M. Ng, H.-C. Chang, L. Ge, C. Rizos, and M. Omura, "Assessment of radar interferometry performance for ground subsidence monitoring due to underground mining," Earth, Planets and Space, vol. 61, no. 6, pp. 733-745, 2009.

[6] Z. Lu, J.-W. Kim, H. Lee et al., "Helmand River hydrologic studies using ALOS PALSAR InSAR and ENVISAT altimetry," Marine Geodesy, vol. 32, no. 3, pp. 320-333, 2009.

[7] H.-S. Jung, Z. Lu, and L. Zhang, "Feasibility of along-track displacement measurement from Sentinel-1 interferometric wide-swath mode," IEEE Transactions on Geoscience and Remote Sensing, vol. 51, no. 1, pp. 573-578, 2013.

[8] M.-E. Pritchard and M. Simons, "Surveying volcanic arcs with satellite radar interferometry: the central Andes, Kamchatka, and beyond," GSA Today, vol. 14, no. 8, pp. 4-10, 2004.

[9] Z. Lu and D. Dzurisin, InSAR Imaging of Aleutian Volcanoes: Monitoring a Volcanic Arc from Space, Springer-Verlag, Berlin Heidelberg, 2014.

[10] E. Chaussard and F. Amelung, "Monitoring the ups and downs of Sumatra and Java with D-Insar time-series," in American Geophysical Union, Fall Meeting, San Francisco, CA, USA, 2010abstract G23C-0838.

[11] S. K. Ebmeier, J. Biggs, T. A. Mather, G. Wadge, and F. Amelung, "Steady downslope movement on the western flank of Arenal volcano, Costa Rica," Geochemistry, Geophysics, Geosystems, vol. 11, no. 12, 2010.

[12] B. Philibosian and M. Simons, "A survey of volcanic deformation on Java using ALOS PALSAR interferometric time series," Geochemistry, Geophysics, Geosystems, vol. 12, no. 11, 2011.

[13] R. Furuta, "Case study of small scale surface deformation detection using ALOS PALSAR differential interferometry," in Proceedings of FRINGE 2009 Workshop, Frascati, Italy, 2009. 
[14] E. Chaussard and F. Amelung, "Precursory inflation of shallow magma reservoirs at west Sunda volcanoes detected by InSAR," Geophysical Research Letters, vol. 39, no. 21, 2012.

[15] C.-W. Lee, Z. Lu, H.-S. Jung, J.-S. Won, and D. Dzurisin, "Surface deformation of Augustine Volcano, 1992-2005, from multiple-interferogram processing using a refined Small Baseline Subset (SBAS) Interferometric Synthetic Aperture Radar (InSAR) approach," in The 2006 Eruption of Augustine Volcano, Alaska, pp. 453-465, U.S. Geological Survey Professional Paper 1769, Alaska, USA, 2011.

[16] C.-W. Lee, Z. Lu, and H.-S. Jung, "Simulation of time-series surface deformation to validate a multi-interferogram InSAR processing technique," International Journal of Remote Sensing, vol. 33, no. 22, pp. 7075-7087, 2012.

[17] Z. Lu, T. Masterlark, D. Dzurisin, R. Rykhus, and C. Wicks Jr., "Magma supply dynamics at Westdahl volcano, Alaska, modeled from satellite radar interferometry," Journal of Geophysical Research: Solid Earth, vol. 108, no. B7, 2003.

[18] Z. Lu, T. Masterlark, and D. Dzurisin, "Interferometric synthetic aperture radar study of Okmok volcano, Alaska, 19922003: magma supply dynamics and postemplacement lava flow deformation," Journal of Geophysical Research: Solid Earth, vol. 110, no. B2, 2005.

[19] T. Masterlark, "Magma intrusion and deformation predictions: sensitivities to the Mogi assumptions," Journal of Geophysical Research: Solid Earth, vol. 112, no. B6, 2007.

[20] H. S. Jung, Z. Lu, J. S. Won, M. P. Poland, and A. Miklius, "Mapping three-dimensional surface deformation by combining multiple-aperture interferometry and conventional interferometry: application to the June 2007 eruption of Kilauea volcano, Hawaii," IEEE Geoscience and Remote Sensing Letters, vol. 8, no. 1, pp. 34-38, 2011.

[21] C.-W. Lee, "Baekdusan volcano time-series analysis from 1992 to 1998 using multi-interferogram InSAR processing," Terrestrial, Atmospheric and Oceanic Sciences, vol. 25, no. 6, p. 743, 2014.

[22] C. W. Lee, Z. Lu, J. W. Kim, and S. K. Lee, "Volcanic activity analysis of Mt. Sinabung in Indonesia using InSAR and GIS techniques," in 2015 IEEE International Geoscience and Remote Sensing Symposium (IGARSS), pp. 4793-4796, Milan, Italy, 2015.

[23] C. W. Lee, S. K. Lee, Z. Lu, and J. W. Kim, "Volcanic activity analysis of Mt. Sinabung in Indonesia using remote sensing and GIS techniques," in Near-Surface Asia Pacific Conference, pp. 150-153, Waikoloa, HI, USA, 2015.

[24] C. W. Lee, Z. Lu, and J. W. Kim, "Monitoring Mount Sinabung in Indonesia using multi-temporal InSAR," Korean Journal of Remote Sensing, vol. 33, no. 1, pp. 37-46, 2017.

[25] C. Widiwijayanti, B. Voight, D. Hidayat, and S.-P. Schilling, "Objective rapid delineation of areas at risk from block-andash pyroclastic flows and surges," Bulletin of Volcanology, vol. 71, no. 6, pp. 687-703, 2009.

[26] B.-E. Hubbard, M.-F. Sheridan, G. Carrasco-Nunez, R. DiazCastellon, and S.-R. Rodriguez, "Comparative lahar hazard mapping at Volcan Citlaltépetl, Mexico using SRTM, ASTER and DTED-1 digital topographic data," Journal of Volcanology and Geothermal Research, vol. 160, no. 1-2, pp. 99-124, 2007.

[27] R.-M. Iverson, S.-P. Schilling, and J.-W. Vallance, "Objective delineation of lahar-inundation hazard zones," Geological Society of America Bulletin, vol. 110, no. 8, pp. 972-984, 1998.
[28] C.-W. Lee, M. Cho, and Y.-J. Choi, "Satellite imagery correction method and system," Korea Patent 10-1303730, 2013.

[29] C.-W. Lee, Z. Lu, J.-S. Won, H.-S. Jung, and D. Dzurisin, "Dynamic deformation of Seguam Island, Alaska, 1992-2008, from multi-interferogram InSAR processing," Journal of Volcanology and Geothermal Research, vol. 260, pp. 43-51, 2013.

[30] G. Nico, R. Tome, J. Catalao, and P. M. A. Miranda, "On the use of the WRF model to mitigate tropospheric phase delay effects in SAR interferograms," IEEE Transactions on Geoscience and Remote Sensing, vol. 49, no. 12, pp. 4970-4976, 2011.

[31] J. Catalao, G. Nico, R. Hanssen, and C. Catita, "Merging GPS and atmospherically corrected InSAR data to map 3-D terrain displacement velocity," IEEE Transactions on Geoscience and Remote Sensing, vol. 49, no. 6, pp. 2354-2360, 2011.

[32] K. Mogi, "Relations between the eruptions of various volcanoes and the deformations of the ground surfaces around them," Bulletin of the Earthquake Research Institute, vol. 36, pp. 99-134, 1958.

[33] R.-J. Blong, "Volcanic hazards risk assessment," in Monitoring and Mitigation of Volcanic Hazards, pp. 675-698, Springer, Berlin, Heidelberg, 1996.

[34] A.-R. Darnell, J.-C. Phillips, J. Barclay, R.-A. Herd, A.-A. Lovett, and P.-D. Cole, "Developing a simplified geographical information system approach to dilute lahar modelling for rapid hazard assessment," Bulletin of Volcanology, vol. 75, no. 4, 2013.

[35] E. Chaussard, F. Amelung, and Y. Aoki, "Characterization of open and closed volcanic systems in Indonesia and Mexico using InSAR time series," Journal of Geophysical Research: Solid Earth, vol. 118, no. 8, pp. 3957-3969, 2013.

[36] C.-S. Magirl, P.-G. Griffiths, and R.-H. Webb, “Analyzing debris flows with the statistically calibrated empirical model LAHARZ in southeastern Arizona, USA," Geomorphology, vol. 119, no. 1-2, pp. 111-124, 2010.

[37] D. O. Dorta, G. Toyos, C. Oppenheimer, M. T. Pareschi, R. Sulpizio, and G. Zanchetta, "Empirical modelling of the May 1998 small debris flows in Sarno (Italy) using LAHARZ," Natural Hazards, vol. 40, no. 2, pp. 381-396, 2007.

[38] M. Iguchi, K. Ishihara, Surono, and M. Hendrasto, "Learn from 2010 Eruptions at Merapi and Sinabung Volcanoes in Indonesia," Disaster Prevention Research Institute Annuals, vol. 54, no. B, pp. 185-194, 2011. 


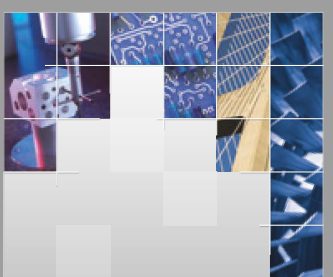

\section{Enfincering}
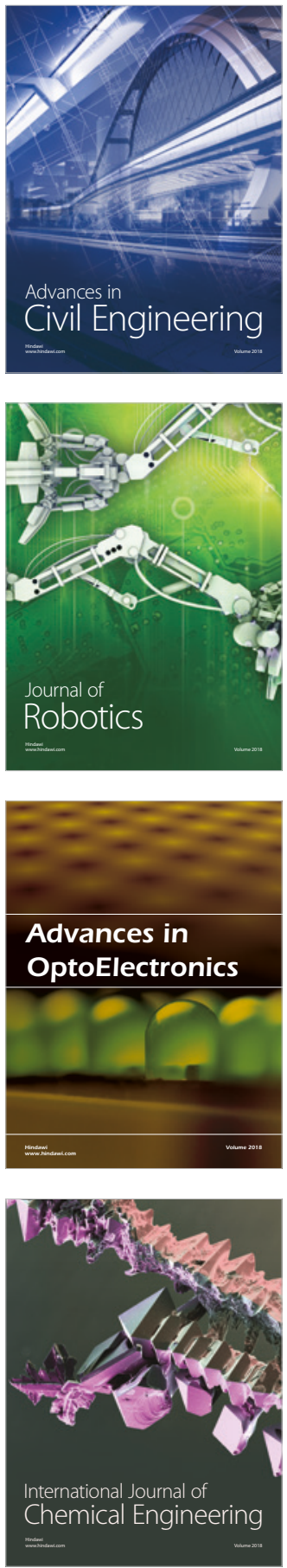

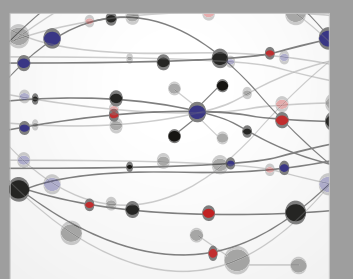

\section{Rotating \\ Machinery}

The Scientific World Journal

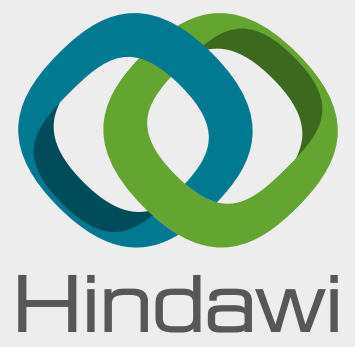

Submit your manuscripts at

www.hindawi.com
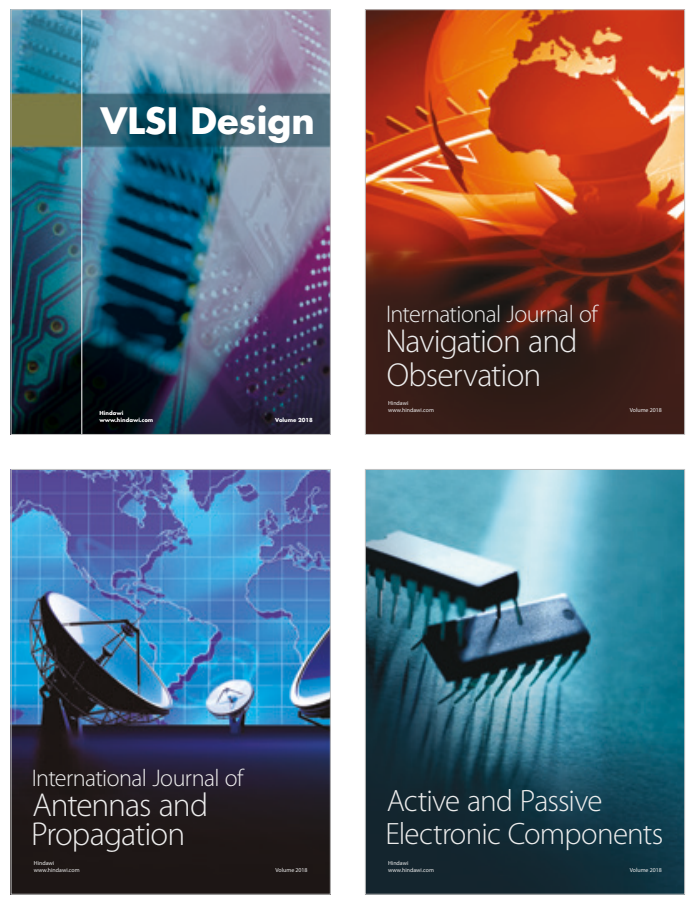
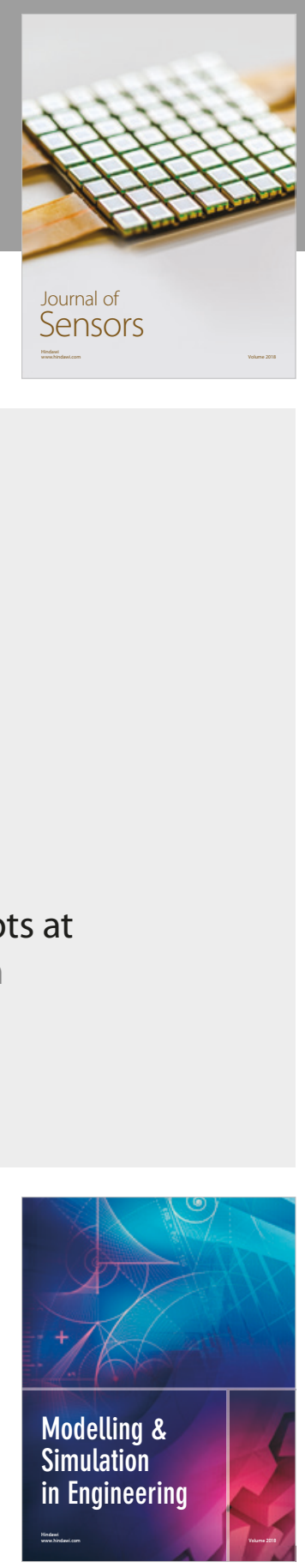

\section{Advances \\ Multimedia}
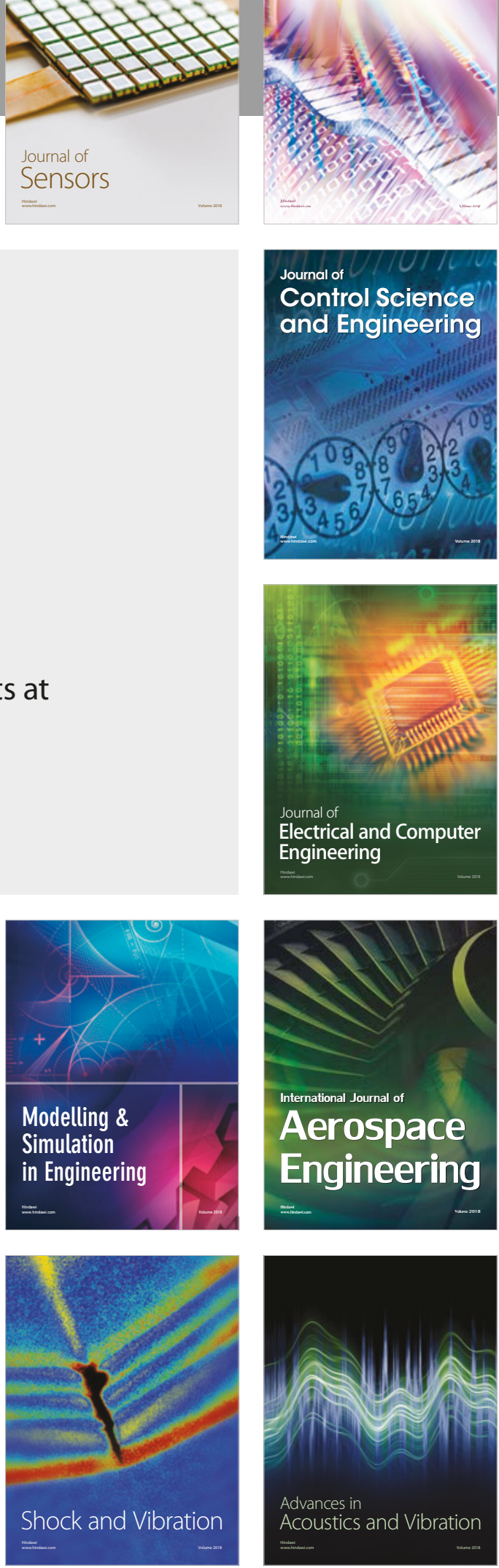